\title{
EXPERIMENTAL STUDY REGARDING THE CORROSION BEHAVIOUR OF HEAT EXCHANGER BRASS TUBES IN THE PRESENCE OF DIFFERENT AGGRESSIVE ENVIRONMENTS
}

Original scientific paper

UDC: $620.193 .4: 662.987$

https://doi.org/10.18485/aeletters.2021.6.3.5

\author{
Ibrahim Ramadan', Maria Tănase ${ }^{1^{*}}$ \\ ${ }^{1}$ Petroleum Gas University of Ploiești , Faculty of Mechanical and Electrical Engineering, Romania
}

\begin{abstract}
:
The study on the tubes (made of CuZn36 material) of a condenser used in petrochemical industry revealed that thickness reduction by corrosion is the main factor causing the decrease of the equipment service life. The present paper aims to study, from the experimental point of view, the behavior of the heat exchanger tubes, in the presence of different environments. The experimental program conducted in the article included two directions: evaluation of technical condition of in-service brass tubes after a certain period of operation for a condenser used in petrochemical industry in order to see how the working conditions affect the brass tubes and an experimental study based on simulation of exposure to extreme corrosive environments for samples taken from new CuZn36 tubes. The goal is to establish their influence on the tubes degradations by determining the corrosion rate. The analyzed samples were immersed in different corrosive solutions for 21 days. Another sample was boiled in water and cooled in air in order to simulate the working environment of the tubes in the condenser. All the samples were weighted before and after the exposure in the aggressive environment, thus establishing the corrosion rate for each of them. In order to analyze from mechanical point of view the influence of the environment on the brass tubes, the flattening test was made, comparing the behavior of the exposed samples with that of the unexposed sample.
\end{abstract}

\section{INTRODUCTION}

A heat exchanger is a heat transfer device that is used for transfer of internal thermal energy between two or more fluids available at different temperatures. In most heat exchangers, the fluids are separated by a heat transfer surface, and ideally they do not mix. Heat exchangers are used in the process, power, petroleum, transportation, airconditioning, refrigeration, cryogenic, heat recovery, alternate fuels, and other industries [1].

Several types of heat exchangers exist, but the most common types are shell-and-tube heat exchangers [2], which is the most commonly used heat exchanger. They are used as oil cooler, surface

\section{ARTICLE HISTORY}

Received: 09.08.2021.

Accepted: 13.09 .2021$.

Available: 30.09.2021.

\section{KEYWORDS}

Heat exchanger, copper, corrosion rate, condenser tubes, flattening test 
secondary (steam plant) system, producing steam from water in the process. These are called steam generators. All fossil-fueled and nuclear power plants using steam-driven turbines have surface condensers to convert the exhaust steam from the turbines into condensate (water) for reuse [3].

The high temperature and aggressiveness of the fluids circulating through the heat exchangers, determine the interaction between the fluids and the metals of the composing elements of heat exchangers. This phenomenon leads to premature degradation of the heat exchangers and implicitly to high costs related to their maintenance and repair [2].

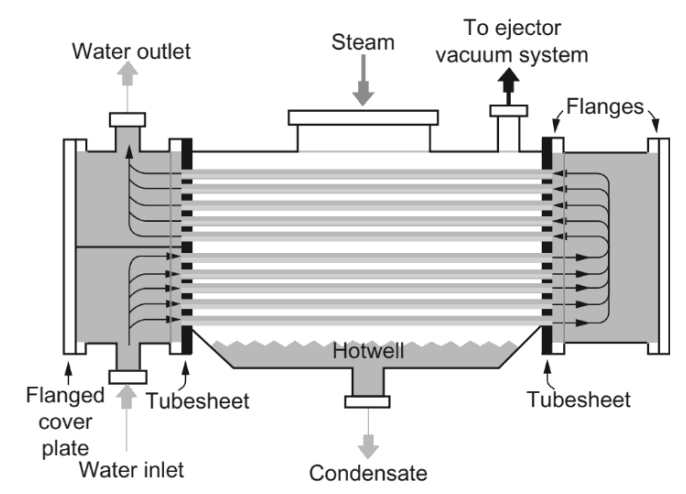

Fig.1. Typical water-cooled surface condenser [3]

The examples from practice have proven that the corrosion is the main cause of failure for the heat exchangers [2]. The danger represented by this phenomenon is illustrated by two cases mentioned in [2].

It is about an offshore gas production platform (2006) and a refinery plant (2010). The first incident, is related to a shell-and-tube heat exchanger, made from carbon steel clad with titanium that was used to cool hydrocarbon gas with seawater. Galvanic corrosion between the carbon steel and titanium cladding caused the escape of the gas into the seawater, over pressuring the shell and thus causing the breakage of the shell tubes. The escaping gas exploded. In the second incident a carbon steel shell-and-tube heat exchanger was involved, in this case the shell cracked at the weld seams, releasing the hot hydrogen and naphtha. The mixture autoignited, resulting in seven fatalities [2].

Condensers tubes are usually made of copperbased alloys because of their excellent heat transfer and corrosion resistance properties [4]. In the most cases, in practice, due to the operating conditions, heat exchanger tubes are damaged as a direct result of corrosion [5-13,22].
The research [14] analyses the failure after 5 years of in service operation of a heat exchanger, using standard metallographic examination, hardness measurement, scanning electron microscopy and $\mathrm{X}$-ray energy dispersion analysis. The damage was due to the erosion-corrosion induced by disturbed flow of water containing suspended solid particles and chemical composition of water rich in chlorides.

The research [15] refers to an experimental failure analysis of copper pipes from three different heat exchanger systems. It was shown that the so called "ant-nest corrosion" could be prevented by using the lubricants oils with low-carboxylic acid content, proper drying and sealing of the pipes prior to storage and drastic removal of all possible contaminants.

The research [16] aims to present the testing results regarding the corrosion damage occurred on the inner surface of copper tubes of a heat exchanger, highlighting that the surface condition related to technological processes and non-metallic inclusions have a very important influence on the corrosion initiation.

The experimental studies from [17] revealed that the boring tube sheet shape with a groove on hole tube shape presents a better corrosion behavior than the shape with smooth hole tube sheet.

The corrosion determines the reduction of the thickness for the heat exchanger components. Thus, the mechanical stresses increase and the material can break. To avoid this phenomenon, tests can be performed in order to determine the corrosion rate. In this way, when such a structure is designed, an appropriate corrosion addition can be considered, increasing the tubes wall thickness.

\section{MATERIALS AND METHODS}

The first step in the experimental investigation of brass tubes was to evaluate the technical condition of in-service brass tubes after a certain period of operation, for a condenser used in petrochemical industry (Fig.2), with the working parameters presented in Table 1 . During a basic periodical technical inspection, samples were taken from the brass tubes in order to evaluate their technical condition.

Determination of the chemical composition was performed with arc spark optical emission 
spectroscopy using the Oxford Instruments Foundry Master-Pro Spectrometer, for samples taken from different areas of the tubular material which worked for different periods of time in the condenser presented in Fig.2. Three determinations were made for the main chemical elements of the tube material and the results obtained are presented in Table 2.

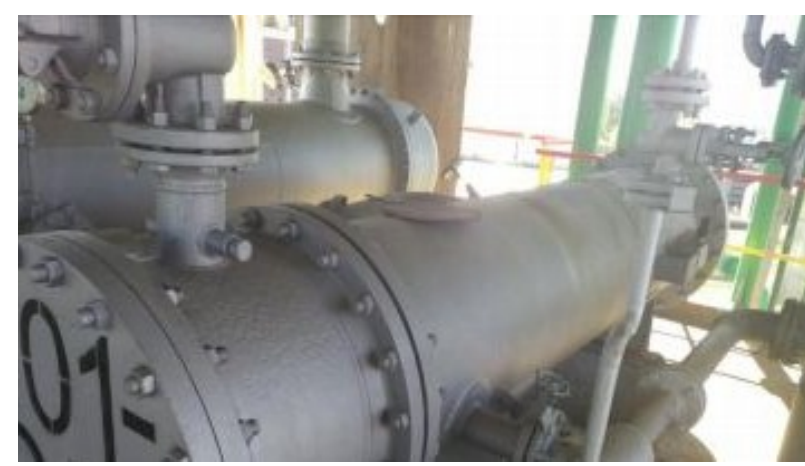

Fig.2. The condenser considered in the case study

Table 1. Characteristics of the condenser analyzed

\begin{tabular}{|l|l|l|}
\hline Characteristic & Value & Unit \\
\hline Tubes outer diameter & 13 & $\mathrm{~mm}$ \\
\hline Tubes thickness & 0.5 & $\mathrm{~mm}$ \\
\hline Total number of tubes & 80 & \\
\hline Tubes material & CuZn36 & \\
\hline $\begin{array}{l}\text { Maximum working } \\
\text { temperature }\end{array}$ & 80 & ${ }^{\circ} \mathrm{C}$ \\
\hline Maximum working pressure & 5 & $\mathrm{bar}$ \\
\hline Design pressure & 7.45 & $\mathrm{bar}$ \\
\hline Shell inner diameter & 700 & $\mathrm{~mm}$ \\
\hline Shell wall thickness & 10 & $\mathrm{~mm}$ \\
\hline Shell material & $\mathrm{P} 265 \mathrm{GH}$ & \\
\hline Mass of the tubes & 1310 & $\mathrm{~kg}$ \\
\hline Mass of the container & 3910 & $\mathrm{~kg}$ \\
\hline Mass of the device & 5290 & $\mathrm{~kg}$ \\
\hline
\end{tabular}

Table 2. Chemical composition for the tubular material which worked in condenser

\begin{tabular}{|c|c|c|c|}
\hline \multirow{2}{*}{$\begin{array}{c}\text { Chemical } \\
\text { element }\end{array}$} & \multicolumn{3}{|c|}{$\begin{array}{c}\text { Content } \\
\text { [\%] }\end{array}$} \\
\cline { 2 - 4 } & Probe 1 & Probe 2 & Probe 3 \\
\hline $\mathbf{C u}$ & 63 & 63.5 & 63.3 \\
\hline $\mathbf{F e}$ & 0.05 & 0.04 & 0.04 \\
\hline $\mathbf{P b}$ & 0.03 & 0.02 & 0.0025 \\
\hline $\mathbf{Z n}$ & 30 & 31.1 & 32 \\
\hline $\mathbf{A l}$ & 0.02 & 0.02 & 0.02 \\
\hline $\mathbf{N i}$ & 0.25 & 0.3 & 0.27 \\
\hline $\mathbf{S n}$ & 0.1 & 0.1 & 0.1 \\
\hline
\end{tabular}

It was found that, due to the working environment, the CuZn36 tubes underwent an intense dezincification process. During dezincification, the more active zinc is selectively removed from the brass, leaving behind a weak deposit of the porous, more noble copper rich metal [18]. This phenomenon appear in copper-zinc alloys containing less than 85 percent copper when they are in contact with water having a high oxygen and carbon dioxide content. The effect tends to accelerate as temperature increases or $\mathrm{pH}$ decreases below 7. Dezincification creates a porous surface in which the zinc is chemically removed from the alloy [19]. The determined $\mathrm{Zn}$ content was lower than the minimum value specified by [20].

For the second direction of the experimental study, a CuZn36 tube was used, with $25 \mathrm{~mm}$ outer diameter and $2 \mathrm{~mm}$ thickness. Several rings of 50 $\mathrm{mm}$ were cut, as can be seen in Fig.3, and immersed in different environments for 21 days.

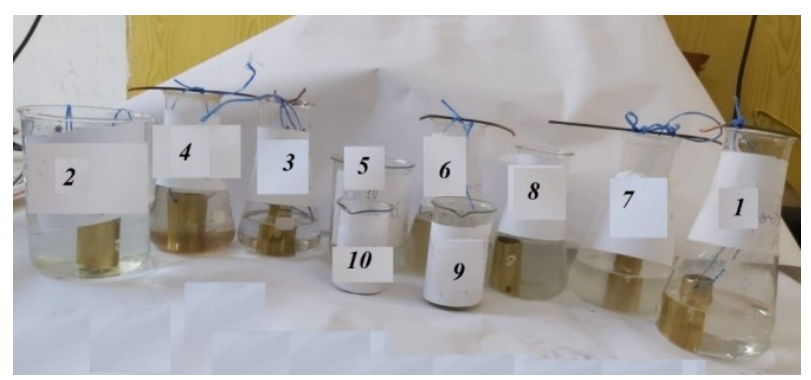

Fig.3. The samples used for the experimental study

The samples markings and the corresponding immersion environments are presented in Table 3.

Table 3. Samples markings

\begin{tabular}{|c|c|}
\hline $\begin{array}{c}\text { Sample } \\
\text { no. }\end{array}$ & $\begin{array}{c}\text { Immersion } \\
\text { environment }\end{array}$ \\
\hline 1 & $\mathrm{H}_{2} \mathrm{O}-$ partial immersion \\
\hline 2 & $\mathrm{H}_{2} \mathrm{O}-$ total immersion \\
\hline 3 & $\mathrm{H}_{2} \mathrm{O}+\mathrm{NaCl}-$ partial immersion \\
\hline 4 & $\mathrm{H}_{2} \mathrm{O}+\mathrm{NaCl}-$ total immersion \\
\hline 5 & $5 \% \mathrm{NaClO}-$ total immersion \\
\hline 6 & $5 \% \mathrm{NaClO}-$ partial immersion \\
\hline 7 & $10 \% \mathrm{NaClO}-$ partial immersion \\
\hline 8 & $10 \% \mathrm{NaClO}-$ total immersion \\
\hline 9 & $100 \% \mathrm{NaClO}-$ partial immersion \\
\hline 10 & $100 \% \mathrm{NaClO}-$ total immersion \\
\hline 11 & boiling water-partial immersion \\
\hline
\end{tabular}

For the simulation of the working environment of the tubes in the analyzed condenser, sample 11, of the same CuZn36 tube was partially immersed in water and boiled 2 hours a day and cooled in the air repeatedly for a 7 days period.

Determination of the corrosion rate involves completing the following steps: samples cutting and 
preparation. The cutting process was made on Metkon Servocut 301-MM Liquid Cooling Metallographic Cutting Machine. Abrasive wet cutting was used in order to avoid damaging the samples with frictional heat.

For laboratory corrosion tests that simulate exposure to service environments a surface closely resembling the one that would be used in service, will yield the most meaningful results [10]. For the tested samples standard surface cleaning was applied. For this purpose, the samples were degreased. After 24 hours of rest, the samples were weighed and quickly introduced in the corrosive environment.

All the samples were immersed in vertical position in containers and were submerged in the considered environment up to half height (partial immersion) or at full height (total immersion).

Three different corrosive solutions were used for immersion: water, sodium chloride $(\mathrm{NaCl})+$ water in volume concentration of $5 \% \mathrm{NaCl}$, or sodium hypochlorite $(\mathrm{NaClO})+$ water in different volume concentration $(5 \%, 10 \%$ or $100 \% \mathrm{NaClO})$. The solution of $\mathrm{NaClO}$ comes from an usual laundry whitener. The water used in the experimental investigation comes from the distribution network in the city of Ploiesti, having the characteristics indicated by the drinking water supplier: $\mathrm{pH}=7.480$, conductivity $=603 \mathrm{microS} / \mathrm{cm}$.

After the test, the samples were removed from the corrosive environment, cleaned of nonadherent products but without removing material unaffected by corrosion, then washed, dried and macro-structural examined. Loose-fitting corrosion products were mechanically removed with sandpaper. In order to determine the corrosion rate in the considered environments, after exposure, the samples were weighed again to calculate the mass difference. The accuracy of the weight used is 0.01 g.

The corrosion rate $R$ [mm/year] was calculated with the following formula [21]:

$$
R=\frac{\left(m_{i}-m_{f}\right)}{A \cdot t \cdot \rho} \cdot 8760
$$

where $m_{i}$ and $m_{f}$ represents the initial, respectively the final mass of the analyzed sample $[g], A$ is the surface area of the sample $\left[\mathrm{mm}^{2}\right], t$ is the exposure time [h] - in this case 504 hours corresponding to 21 days, $\rho$ is the density of the sample material $\left[\mathrm{g} / \mathrm{mm}^{3}\right]$ - in this case $8.44 \cdot 10^{-3} \mathrm{~g} / \mathrm{mm}^{3}[20]$.

In order to mechanically estimate what happened to the exposed tubes, the flattening test was used [23], so test pieces of $10 \mathrm{~mm}$ were cut from the exposed samples (Fig.4 and Fig.5).

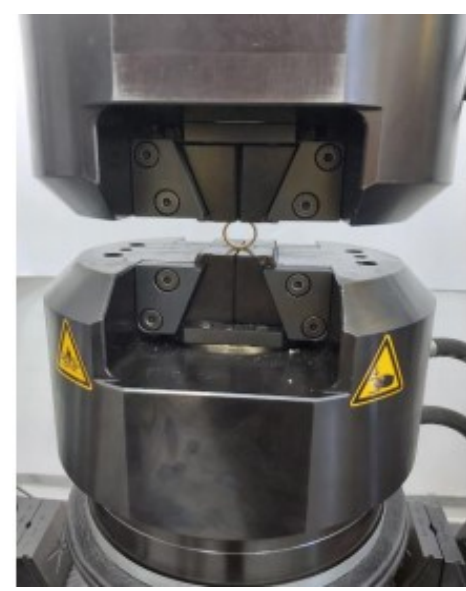

Fig.4. The device used for the flattening test

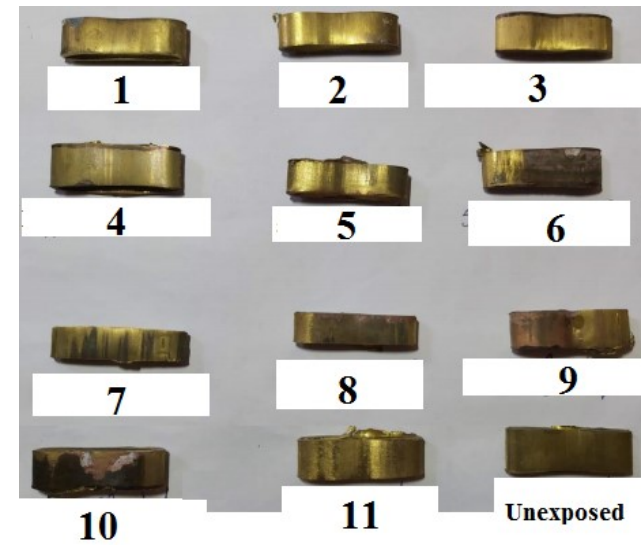

Fig.5. The samples after the flattening test

The test pieces were placed between the two platens of the Walter Bai LF300 Universal Testing Machine, the rate of movement of the platens was $5 \mathrm{~mm} / \mathrm{min}$ and a load was applied until the internal surfaces were in contact. The tests were carried out at ambient temperature $\left(22^{\circ} \mathrm{C}\right)$.

\section{RESULTS AND DISCUSSIONS}

In Table 4 the final aspect of the samples can be seen. For the sample 11 (boiled), a degradation of the outer surfaces of the tube at the interface between the liquid and the gas can be observed, confirmed by the actual decrease in thickness in this area (from $2 \mathrm{~mm}$ to $1.74 \mathrm{~mm}$ ). The thickness reduction was determined with digital wall ultrasonic thickness gauge Sauter TD 225-0.1 US.

Also, Table 4 presents the final aspect and the corrosion rates for all the samples immersed in the considered environments. The comparison between the calculated corrosion rates for the samples exposed is presented in Fig.6. 
The results of the flattening test are presented in Table 4.

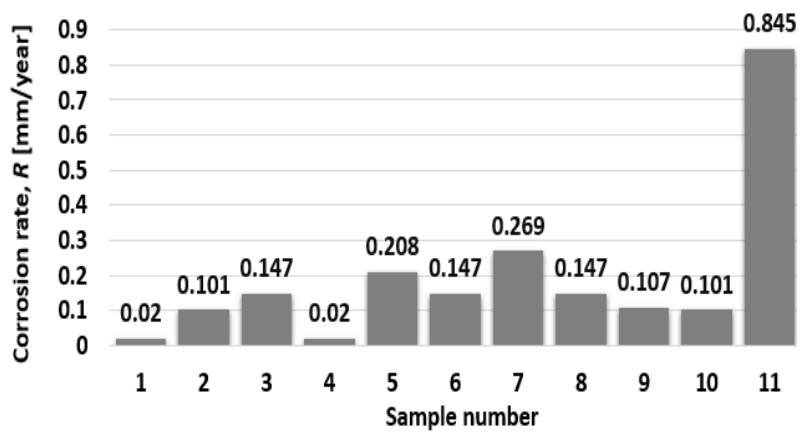

Fig.6. Comparison between the corrosion rates for different immersion environment

It can be seen that for the exposed samples, the load necessary to bring in contact the internal surfaces of the test pieces were smaller than for the unexposed sample, resulting that their mechanical characteristics were negatively influenced.

Table 5, containing the results of flattening test, leads to conclusion that the tubes under $\mathrm{NaClO}$ solutions in different volume concentrations have lower mechanical properties because the load necessary to bring in contact the internal surfaces of the test pieces was with $15.78 \% . . .37 .5 \%$ lower compared with the unexposed sample, increasing with the $\mathrm{NaClO}$ concentration.

The influence of different aggressive environments can be easily evaluated by determining the corrosion rate. From the Fig.5 it results that the most affected is sample 11 which was boiled, meaning that the CuZn36 material is mostly affected by the presence of water at high temperatures, so the specific working conditions of condensers will eventually led to acute corrosion of tubes. The samples immersed in $\mathrm{NaClO}$ solutions were more affected than the samples immersed in water or $\mathrm{NaCl}$ solutions.

Similar studies were found in the research made by other authors. An investigation for determining the corrosion rate was made in [4] for samples of copper alloy tubes of $13.5 \mathrm{~mm}$ diameter. This study followed the influence of water flow conditions and temperature on the corrosion rate of cooper tubes. The obtained values of corrosion rate were between 0.0014 and $0.174 \mathrm{~mm} /$ year.

The research [24] presents the results concerning corrosion tests for brass tubes exposed to water with different concentration of chlorine. The exposure time was 30,60, 90 and 180 days. The determination of corrosion rate was made by gravimetric tests, same as in the present study. The corrosion rate increased with the chlorine concentration from $0.139 \mathrm{~mm} /$ year to 0.907 $\mathrm{mm} /$ year, so the values are similar with the values obtained in the present study.

Some methods described by [25] regarding active anode protection in order to reduce wear can also be applied for heat exchangers.

\section{CONCLUSION}

The study was made on several samples both total and partially immersed, in different corrosive solutions (water, sodium chloride $(\mathrm{NaCl})+$ water or sodium hypochlorite $(\mathrm{NaClO})+$ water in different volume concentration)

The results obtained highlight the fact that the material is mostly affected by the presence of water at high temperatures. Also, it can be observed that the corrosion rate is high in the case of immersion in water and solution with $5 \%$ or $10 \% \mathrm{NaClO}$. It was found that CuZn36 tubes underwent an intense dezincification process.

The flattening test revealed that the presence of water at high temperatures and steam considerably affects the material, in the case of this sample the lowest displacements were obtained, this conclusion being in accordance with the corrosion rate results. So water at high temperatures and steam have a negative effect on the mechanical behavior of CuZn36 tubes.

Although it is not recommended to use CuZn36 tubes in chlorine environments, following the experimental study it was determined that the working environment (water and steam at high temperatures) causes the degradation of the tubes in a similar way.

The corrosion rate results can be used to predict the useful life of CuZn36 tubes. The gravimetric method is simple and useful to apply in order to determine the corrosion rate.

It is necessary to ensure the compatibility between heat exchanger tube materials and operating fluid.

Different boiling and cooling cycles can be used in order to accelerate the specific degradation processes for CuZn36 samples so further detailed studies will be performed in future articles in this regard. 
Table 4. Determination of corrosion rate

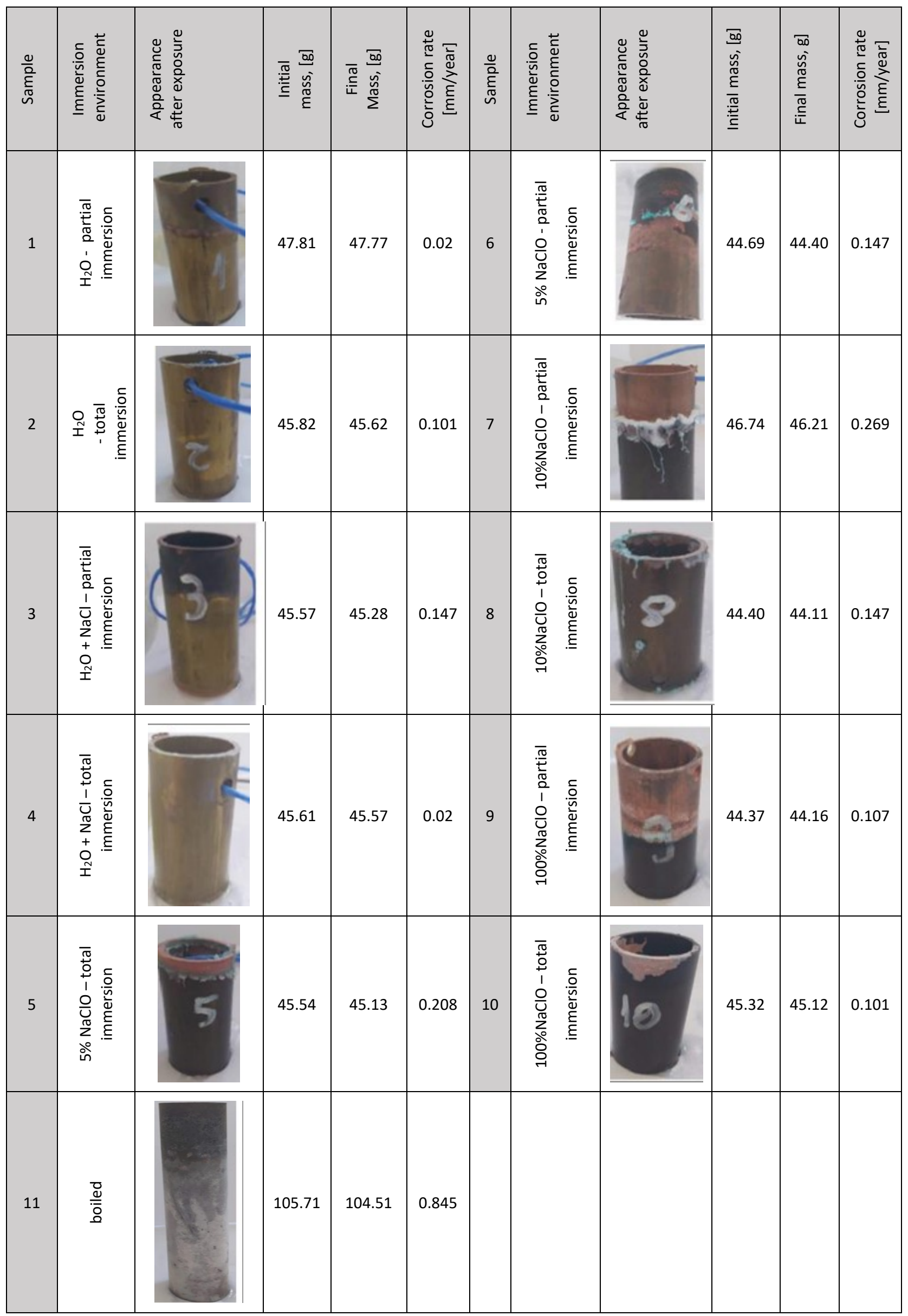


Table 5. Values recorded during the flattening test

\begin{tabular}{|c|c|c|c|c|c|}
\hline Sample & $\begin{array}{l}\text { Immersion } \\
\text { environment }\end{array}$ & $\begin{array}{l}\text { Force } \\
{[k N]}\end{array}$ & $\begin{array}{c}\text { Difference from } \\
\text { unexposed } \\
\text { sample } \\
{[\%]} \\
\end{array}$ & $\begin{array}{l}\text { Displacement } \\
{[\mathrm{mm}]}\end{array}$ & $\begin{array}{c}\text { Difference from } \\
\text { unexposed } \\
\text { sample } \\
{[\%]} \\
\end{array}$ \\
\hline 1 & $\begin{array}{c}\mathrm{H}_{2} \mathrm{O}- \\
\text { partial immersion }\end{array}$ & 2.2 & 0 & 16 & -9.37 \\
\hline 2 & $\begin{array}{c}\mathrm{H}_{2} \mathrm{O}- \\
\text { total immersion }\end{array}$ & 2.05 & -7.31 & 16.5 & -6.06 \\
\hline 3 & $\begin{array}{c}\mathrm{H}_{2} \mathrm{O}+\mathrm{NaCl}- \\
\text { partial immersion }\end{array}$ & 2.1 & -4.76 & 16 & -9.37 \\
\hline 4 & $\begin{array}{c}\mathrm{H}_{2} \mathrm{O}+\mathrm{NaCl}- \\
\text { total immersion }\end{array}$ & 2.2 & 0 & 16.2 & -8.02 \\
\hline 5 & $\begin{array}{c}5 \% \mathrm{NaClO}- \\
\text { total immersion }\end{array}$ & 1.9 & -15.78 & 17.2 & -1.74 \\
\hline 6 & $\begin{array}{c}5 \% \mathrm{NaClO}- \\
\text { partial immersion }\end{array}$ & 1.8 & -22.2 & 16.5 & -6.06 \\
\hline 7 & $\begin{array}{c}10 \% \mathrm{NaClO}- \\
\text { partial immersion }\end{array}$ & 1.8 & -22.2 & 16.7 & -4.70 \\
\hline 8 & $\begin{array}{l}10 \% \mathrm{NaClO}- \\
\text { total immersion }\end{array}$ & 1.8 & -22.2 & 15.5 & -12.90 \\
\hline 9 & $\begin{array}{c}100 \% \mathrm{NaClO}- \\
\text { partial immersion }\end{array}$ & 1.6 & -37.5 & 16 & -9.37 \\
\hline 10 & $\begin{array}{l}100 \% \mathrm{NaClO}- \\
\text { total immersion }\end{array}$ & 1.6 & -37.5 & 15.5 & -12.90 \\
\hline 11 & boiled & 1.8 & -22.2 & 14 & -20 \\
\hline 12 & unexposed & 2.2 & - & 17.5 & - \\
\hline
\end{tabular}

\section{NOTE}

The abstract of this paper is published at the $10^{\text {th }}$ International Conference on Tribology BALKANTRIB '20 organised in Belgrade, on May 2022, 2021.

\section{REFERENCES}

[1] T. Kuppan, Heat Exchanger Design Handbook, Second edition, CRC Press, 2013.

[2] W. Faes, S. Lecompte, Corrosion and corrosion prevention in heat exchangers. Corrosion reviews, 37 (2), 2019: 131-155.

https://doi.org/10.1515/corrrev-2018-0054

[3] G. Barker, The Engineer's Guide to Plant Layout and Piping Design for the Oil and Gas Industries. Gulf Professional Publishing, 2017.

[4] M. Mahmood, The effects of water flow rate on copper corrosion. Key Engineering Materials, 748, 2017: 235-239.

https://doi.org/10.4028/www.scientific.net/K EM.748.235
[5] M. Nitsche, Heat Exchanger Design Guide: A Practical Guide for Planning, Selecting and Designing of Shell and Tube Exchangers. Elsevier Science, 2015.

[6] A. Fraas, Heat Exchanger Design. John Wiley \& Sons, 1991.

[7] R. Shah, D. Sekulic, Fundamentals of Heat Exchanger Design. Wiley \& Sons, 2003.

[8] M. Holger, Heat exchangers. Routledge, 2018.

[9] Zanotto, V. Grassi, A. Balbo, M.E. Touhami, I. Mansouri, C, Corrosion Behavior of Different Brass Alloys for Drinking Water Distribution Systems, Metals, 9, 649, 2019. https://doi.org/10.3390/met9060649

[10] K. Ravindranath, Failure investigation of brass heat exchanger tube - Engineering Failure Analysis 26 2012: 332-336. https://doi.org/10.1016/i.engfailanal.2012.07. $\underline{018}$

[11] P. R. Mondi, Investigation on Heat Exchanger Pipe Failure. Journal of Failure Analysis and Prevention, 19 (5), 2019: 1720-1725. https://doi.org/10.1007/s11668-019-00774-z 
[12] A. Usman, A.N. Khan, Failure analysis of heat exchanger tubes. Engineering Failure Anaysis 15, (1-2), 2008: 118-128.

https://doi.org/10.1016/j.engfailanal.2006.11. $\underline{051}$

[13] M. Lachowicz, A metallographic case study of formicary corrosion in heat exchanger copper tubes. Engineering Failure Analysis, 111, 2020. https://doi.org/10.1016/j.engfailanal.2020.10 4502

[14] B. Kuznicka, Erosion-corrosion of heat exchanger tubes. Engineering Failure Analysis 16, (7) 2009: 382-2387.

https://doi.org/10.1016/j.engfailanal.2009.03. $\underline{026}$

[15] L. Cozzarini, I. Marsich, C. Schmid, Ant-nest corrosion failure of heat exchangers copper pipes. Engineering Failure Analysis 109, 2020: 104387.

https://doi.org/10.1016/i.engfailanal.2020.10 $\underline{4387}$

[16] M.M. Lachowicz, A metallographic case study of formicary corrosion in heat exchanger copper tubes. Engineering Failure Analysis, 111, 2020: 104502.

https://doi.org/10.1016/j.engfailanal.2020.10 4502

[17] M. lancu, R.G. Rîpeanu, I. Tudor, Heat exchangers tube to tube sheet joints corrosion behavior. Tribology in Industry, 35 (1), 2013: 19-24. https://www.tribology.rs/journals/2013/2013 $-1 / 2 . p d f$

[18] S.B. Lyon, Corrosion of Noble Metals, Reference Module in Materials Science and Materials Engineering. Shreir's Corrosion, 3, 2010: 2205-2223.

[19] M.P. Schwartz, Four types of heat exchanger failures. Plant Eng. 23, 1982: 45-50.

[20] EN 12449, Copper and copper alloys. Seamless, round tubes for general purposes, 1999.

[21] ASTM G1 Standard Practice for Preparing, Cleaning, and Evaluation Corrosion Test Specimens, 2003.

[22] M. Stewart, L. Oran. O.T. Lewis, Heat Exchanger Equipment Field Manual: Common Operating Problems and Practical Solutions, Gulf Professional Publishing, 2012.

[23] ISO 8492:2013, Metallic materials - Tube Flattening test, 2013.

[24] F. García-Ávila, G. Bonifaz-Barba, S. DonosoMoscoso, L.F. Pino, L. Ramos-Fernándezae, Dataset of copper pipes corrosion after exposure to chlorine, Data in Brief, 19, 2018: 170-178. https://doi.org/10.1016/j.dib.2018.05.023

[25] R.G. Rîpeanu, V. Ispas, D. Ispas, Review above applying active anode protection at some dynamic petroleum equipment's in order to reduce wear. FME Transactions, 43 (3), 2015: 192-205.

https://doi.org/10.5937/fmet1503198R 